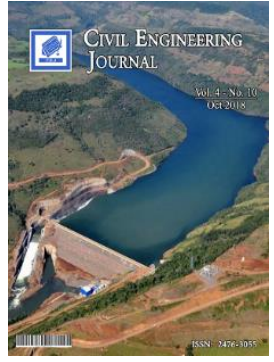

\title{
Analyzing Design Principles of Biophilic Neighborhoods
}

\author{
Elham Asadzadeh ${ }^{a^{*}}$, Maryam Yousefi Ahmadchali ${ }^{\text {a }}$ \\ ${ }^{a}$ Faculty of Architecture and Urbanism, Urban Planning and Design Department, Shahid Beheshti University, Tehran, Iran.
}

Received 25 June 2018; Accepted 12 October 2018

\begin{abstract}
In current century, cities face rapidly evolving challenges, including climate change, resource shortages, population growth and urbanization, and financial pressures. Biophilic urbanism is an emerging design principle capable of considering the multidimensional and interdependent complexities of urban systems and infrastructure, which through the use of natural design features, can meet society's inherent need for contact with nature, and assist efforts to respond to these growing challenges. The purpose of this research is assessment Biophilic criteria in Iran metropolitan. In this research has been mentioned five criteria and 15 patterns. The quantitative and qualitative methods has been used. Data collection methods are observation and questionnaire. Also, has been used AHP method in order to comparison between criteria and patterns. Findings show the most important criteria is biodiversity in order to achieving Biophilic neighborhood. Other principles are bio mimicry, prospect, and the sense of playfulness, enigmatic.
\end{abstract}

Keywords: Sustainability; Biophilic Design; Biophilic Neighborhood; Biophilic Criteria.

\section{Introduction}

There are some urban problems in current century such as in creasing population, increasing demand for energy consumption, air pollution and etc. due to these problems, it is necessary that are some factors to support the clean, sustainable and renewable energy [1]. Within this complex and multidisciplinary problem context, sustainable movement and other proposed approach such as new urbanism, green city, walk-able city, healthy city, efforts are required to find rapid and transformational solutions $[2,3]$. The literature on neighborhood planning movement are namely garden city, neighborhood unite, modernism, neo traditional planning and eco-urbanism [4].

At first, Ebenezer Howard is widely known as person who started the new way utopian thinking. His utopia is garden city [5]. In continue, Clarence Perry, offered the neighborhood unite as instrument for addressing social problems such as alienation, youth delinquency through enhancing the physical design of community [6-8]. At finally, the end of 20 century, has been a global diffusion of initiatives that attempt to integrate sustainability principles in to neighborhood development.

In 1970, sustainable development is proposed by Brantland commission. Sustainable urbanism are urban design with nature and creating better communities. Sustainable urbanism, on the other hand, is more focused on designing on communities that are walk able and transit- served so that people with prefer to meet their daily need to foot .

One of the sustainable urbanism is green urbanism. Propose of green and sustainable urbanism are urban design with nature and creating better communities. In current years, in order to achieving sustainable development is Biophilic architecture and design. Biophilic approach believed that human need daily contact with nature to be productive and healthy, that contact with nature informs human evolved as part of winder nature $[9,10]$. Biophilia thesis or Biophilic

* Corresponding author: elham_asadzadeh@yahoo.com

do) http://dx.doi.org/10.28991/cej-03091170

$>$ This is an open access article under the CC-BY license (https://creativecommons.org/licenses/by/4.0/).

(C) Authors retain all copyrights. 
urbanism attempt the incorporation of international natural design feature across cities, neighborhood and building [10]. Biophilic approach or Biophilic urbanism focuses how cities should be designed based on natural features from international level to individual level [11]. There are some factors observed globally in cities that have integrated nature within their built environment $[12,13]$. Biophilic neighborhood are designed by various traditional factors such as gardening, vegetation cover and etc. [10].

The Context for the Consideration of Biophilic urbanism in this paper is that the population of most major Iranian cities (Mashhad metropolitan in this research) is anticipated to grow rapidly over the next several decades. The purpose of this paper is to consider how Biophilic urbanism complements improve approaches for the built environment in Iran. On the other hand, this study attempt create city that integrate in to nature. Urban nature - also referred to as urban greening and green infrastructure - has increasingly been considered from many perspectives to address challenges such as population pressures, climate change and resource shortages. Within this context, the authors highlight how "Biophilic urbanism" complements and may enhance approaches and efforts for urban greening.

On the other hand, Pollution (air, water, soil, etc.), waste management, and biodiversity depletion are the most important environmental problems of metropolitan of Iran city such as Mashhad. This paper considers the Biophilic urbanism as a complementary approach alongside the other strategies and plans to promote the environmental sustainability in Mashhad city. On the other hand, due to there isn't Biophilic urbanism as a new approach between Iranian metropolitan, so this research is innovative.

\section{Material and Methods}

This article explores the impact of Biophilic design on urban neighborhood, with special focus on the role of nature as part of society. An extensive literature review on Biophilic design was done to identify Biophilic design components [14]. The research method is "analytical- descriptive". The purpose of study is to review and prioritize Biophilic architecture patterns in design to achieve sustainable neighborhood. In this research has been used both of qualitative and quantitative methods. At first section was studied literature in order to achieving list of Biophilic elements that has been concluded from definitions, scientific viewpoints and author observation. In second section, design data collection (questionnaire). Also was used AHP technique. This technique reduces complex decisions into a number of simple comparisons and ratings; and extracting results not only helps the analyst to make the best decision, but also provides a clear rationale to choose. Analytic hierarchy process aims to identify preferred options and also determine rank of alternatives by taking into account all decision criteria [15]. Analytic hierarchy process is an effective and operational approach which is able to consider unstructured and complex decisions. At finally, would be proposed ranking of Biophilic components in order to achieving sustainable neighborhood in Mashhad metropolitan.

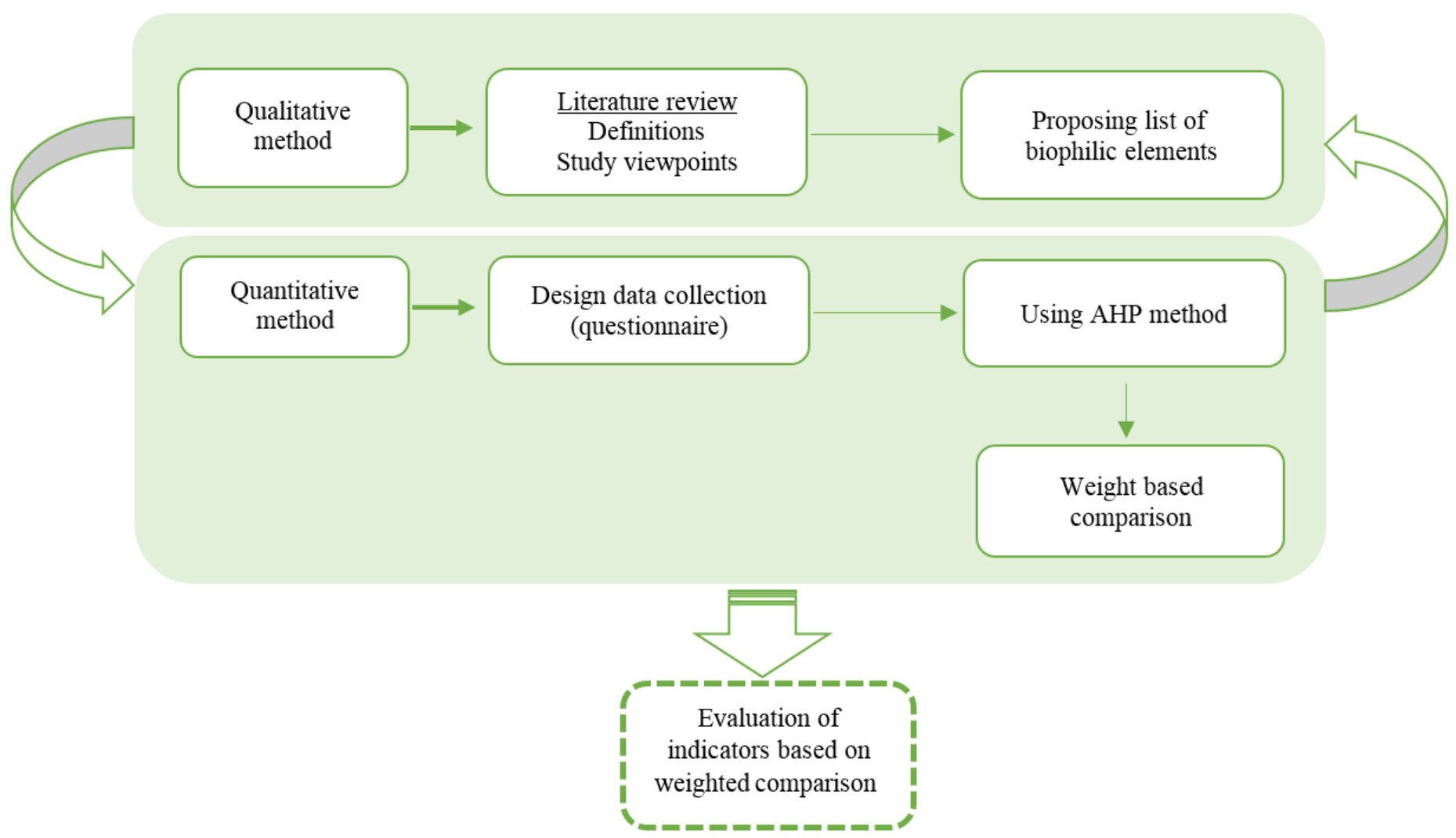

Figure 1. The research method 


\section{Literature Review}

\subsection{Biophilic Concept}

The Biophilia hypothesis developed by Edward Wilson and Stephen Kellert. It emerged through Conversation between many urban theoreticians, architectures and the researches that working about green cities or sustainable city. In deed this approach is proposed in continuing sustainable development [9]. In 2008 is published " Biophilic Design: The Theory, Science and Practice of Bringing Buildings to Life [16]. On the other hand, Timothy Beatley, who also contributed a chapter to Biophilic Design published his book Biophilic cities, Integrating Nature into Urban Design and Planning in 2011to expand the concept of Biophilic design beyond the field of architecture and Individual structures, buildings and sites to cities and the many diverse professions and Urban design, planning and development.

Beatley proposes a number of indicators for what might constitute a Biophilic city, which include considerations for the amount of green space within a city; how accessible this is the types of green space that might be included the existence of organizations and activities that encourage contact with nature [9].

Forms of nature, or "Biophilic elements", are able to be classified into a taxonomy related to the scale. The level of a building, street, and city.

- Building scale elements are those that can be integrated onto, into and around a building, and are generally assumed to be limited to an individual property parcel.

- Street scale elements are those integrated into and alongside streets, roads and sidewalks, and parcel-sized blocks of land (for example vacant blocks of land within a residential suburb).

- City scale Biophilic elements are larger size and likely to be fewer in number. These are not integrated into the urban fabric in the way that building or street scale elements are, and are instead large areas of vegetated space or open water within the city.

Prior studies have tended to explore the impact of greenery in actual stores, window displays, shopping districts, and enclosed malls on shopper emotions, attitudes [17], feelings of arousal and pleasure [18], and well-being [19]. But in current years, researchers believe Biophilic city as a green city, a city with abundant nature and natural systems that are visible and accessible to urbanites. It is not only about physical conditions and urban design (parks, green features, urban wildlife, and walkable environments), but also about the spirit of a place [20]. Biophilic store design may offer an explanation for the increasingly popularity of lifestyle centers, despite the decline of traditional malls, including regional and super-regional centers [21,22]. The goal of Biophilic urbanism is to ameliorate the contemporary urban disconnect with nature, making the experience of the natural world a more integral part of ordinary city life [23].

In 2012, Reeve has been proposed taxonomy of Biophilic elements in three levels. The features of building space scale, are many installations, small in size, retrofit possible, high technical requirement, private and public property. Also, the features of street level are many installations, small-med in size, retrofit possible, public land, high technical requirements and the feature of city scales are few installations, large in size, retrofit difficult, low technical requirement, public land (Table 1) [24].

Table 1. Taxonomy of Biophilic elements [24]

\begin{tabular}{|c|c|c|}
\hline $\begin{array}{l}\text { Scales of Biophilic } \\
\text { concept }\end{array}$ & forms of Biophilic concept based on their scale & Taxonomy of Biophilic elements \\
\hline Building scale & $\begin{array}{c}\text { City parks, linear green space, urban agriculture, } \\
\text { urban waterway }\end{array}$ & $\begin{array}{l}\text { many installations, small in size, retrofit possible, high technical } \\
\text { requirement, private and public property }\end{array}$ \\
\hline Street scale & Pocket parks, street integrated vegetation & $\begin{array}{c}\text { many installations, small-med in size, retrofit possible, public } \\
\text { land, high technical requirements }\end{array}$ \\
\hline City scale & $\begin{array}{l}\text { Green roofs, green walls, shade trees, vegetation } \\
\text { around building }\end{array}$ & $\begin{array}{c}\text { are few installations, large in size, retrofit difficult, low technical } \\
\text { requirement, public land }\end{array}$ \\
\hline
\end{tabular}

Table 2 has been shown Summary of biophilic design elements at the building, neighborhood and city scale that has been adapted from [24]. 
Table 2. Summary of Biophilic design elements

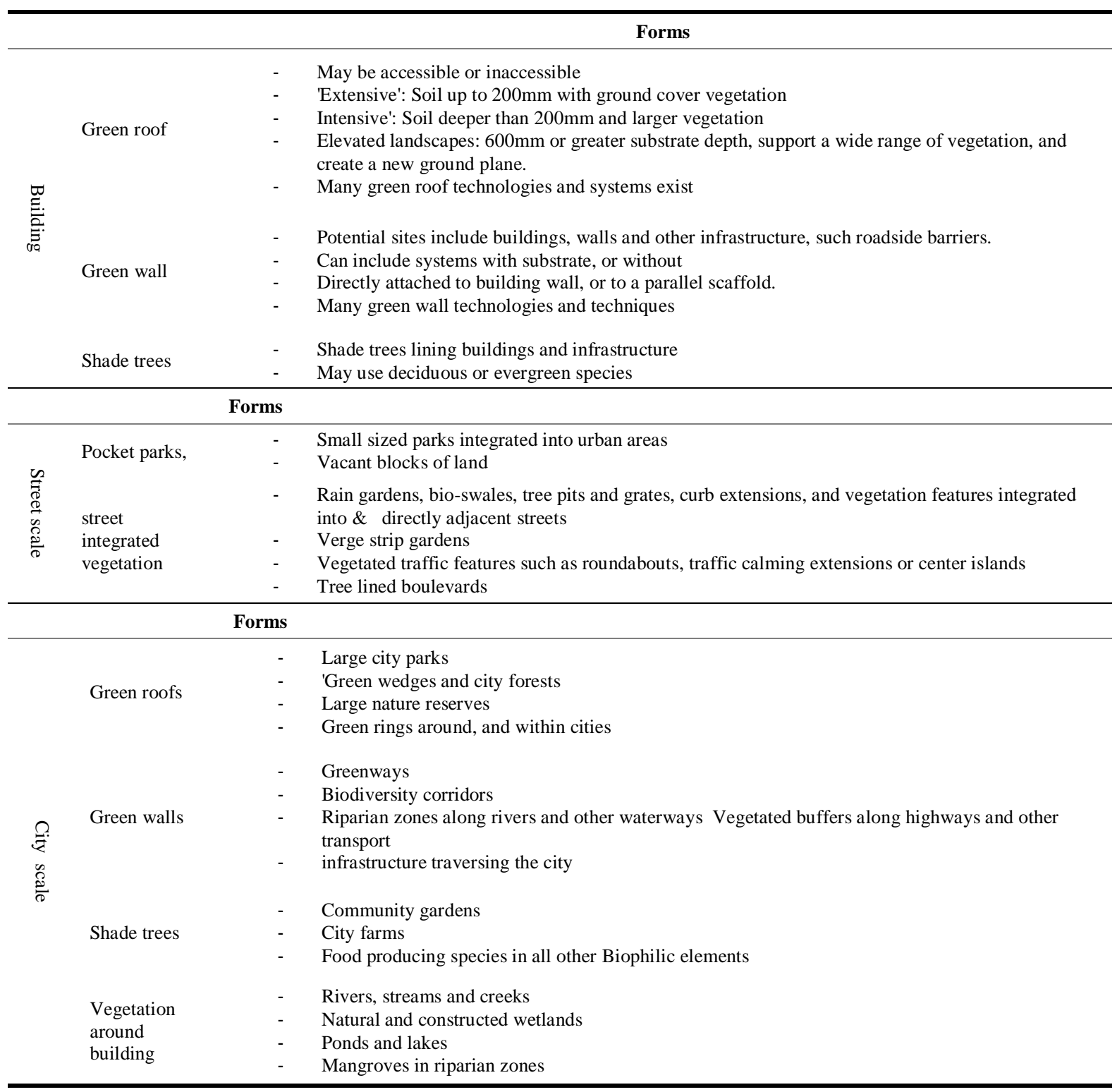

There are definitions and characterize about Biophilic concept in different cities. On the other hand, many scientific have been done research in countries such as Australian, American and Europa. Also, has been proposed characterize according to their context. The six cities are pioneer in Biophilic approach. These include: Toronto, Canada; Portland, U.S.A.; Chicago, U.S.A.; Berlin, Germany; Freiburg, Germany; and Singapore. Table 3 show Biophilic elements in mentioned cities.

Table 3. Biophilic elements in six cities in world [12]

\begin{tabular}{cc}
\hline Biophilic cities & Biophilic elements \\
\hline Toronto, Canada & Green roof \\
Portland, U.S.A. & Green streets and green roofs \\
Chicago, U.S.A. & Green roofs, parkland, street trees, building landscaping \\
Berlin, Germany & Parks, spontaneous, vegetation, building integrated vegetation, tree lined streets \\
Freiburg, Germany & Compact green wedges, storm water infrastructure, vegetated \\
Tingapore & Tram tracks \\
\hline
\end{tabular}

Based on studied Biophilic elements and different scientific ideas, in order are classified criteria in five sections. They include:

- Bio mimicry

- Prospect 
- Biodiversity

- Sense of playfulness (Vitality)

- Enigmatic

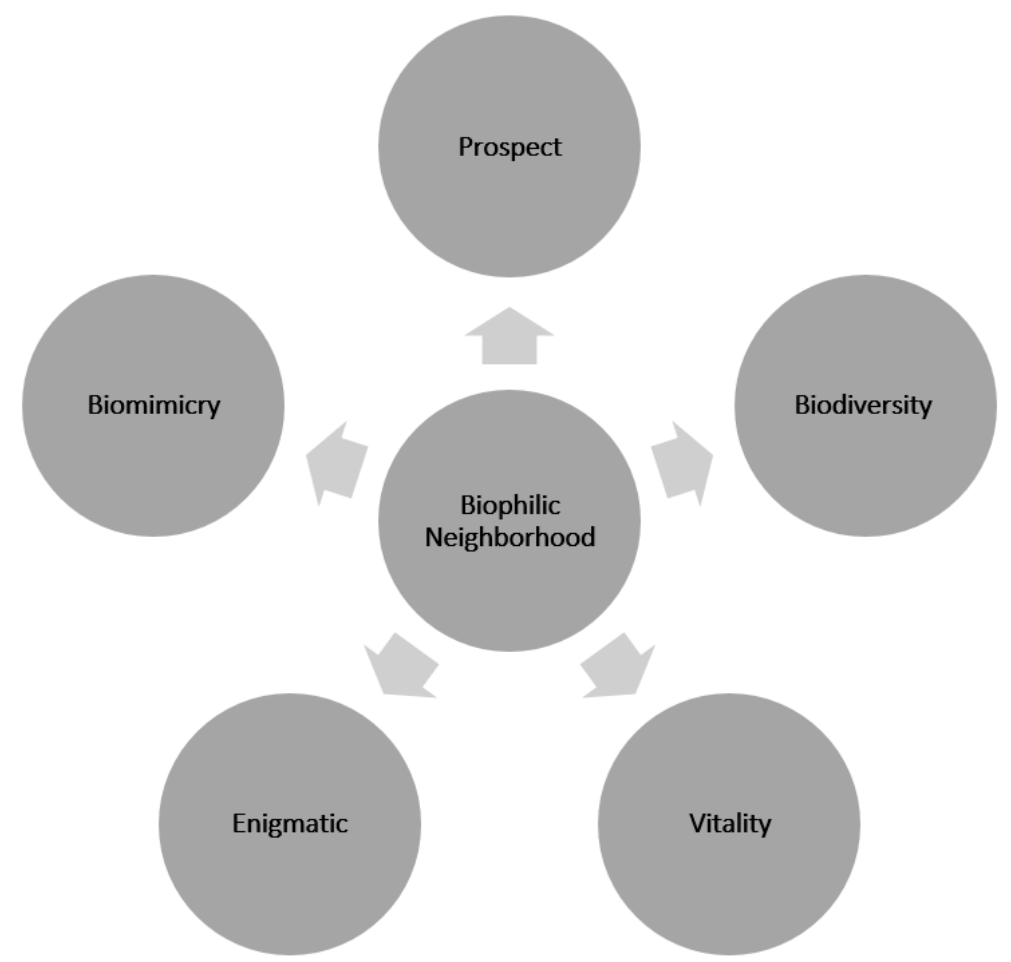

Figure 2. Elements framework classifications to be used for assessing Biophilic neighborhood

Their topic classification was used in this study as they categorized all the themes of all Biophilic neighborhood assessment systems into 15 pattern as shown in Figure 3.

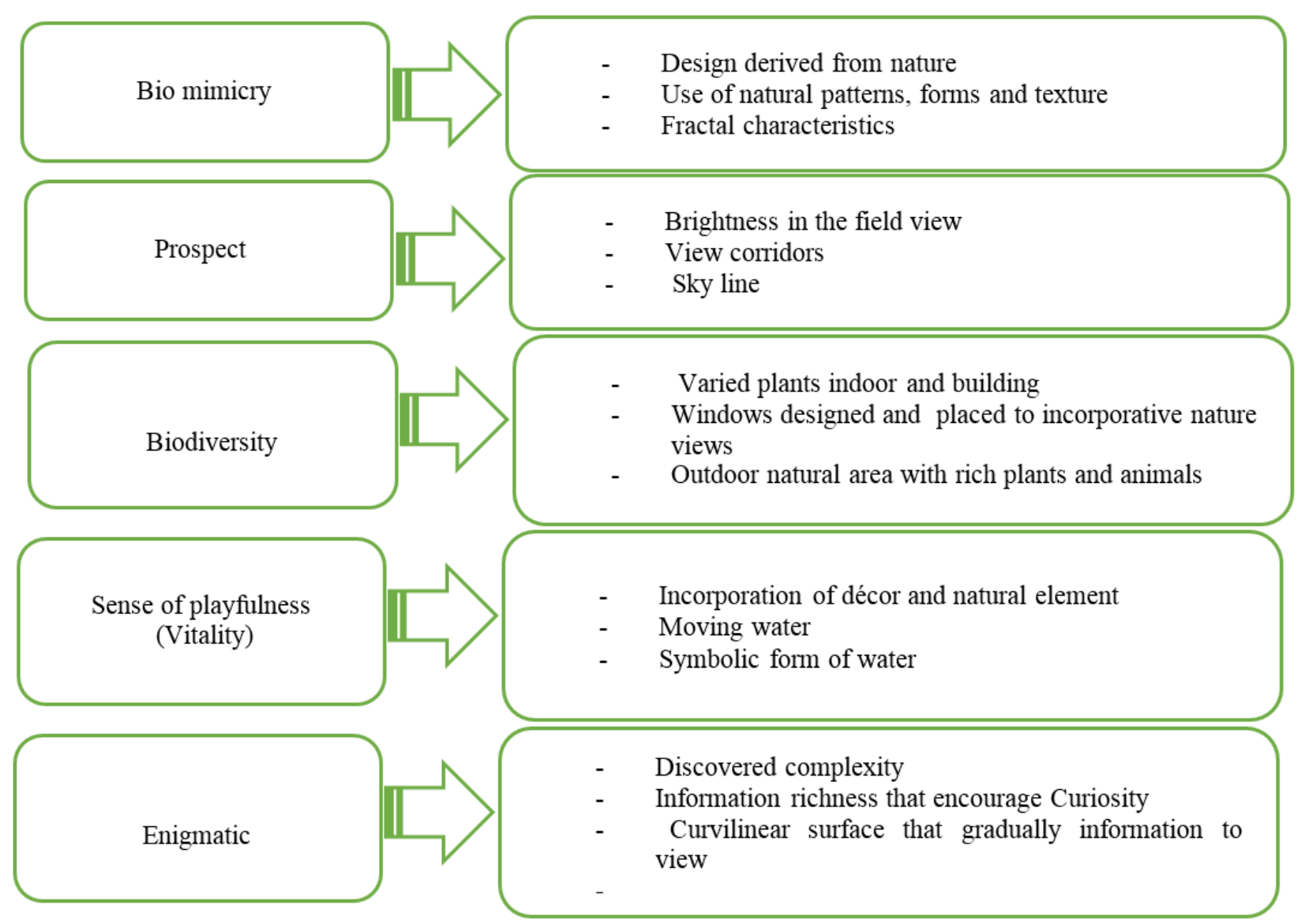

Figure 3. Criteria and patterns of Biophilic neighborhood assessment 
Recent literature on the subject confirms the need for integrating aspects of nature into urban environments. Biophilic urbanism is emerging as a planning and design approach for holistic improvement of urban spaces with combined focus on physical setting, urban design, lifestyle as well as attitudes and experiences [25]. If urban development does not increase the presence of nature, overcoming past or ongoing depletion and damage to nature, the natural life support system will eventually collapse [26].

\section{Results and Discussions}

\subsection{AHP Method}

AHP is a method allowing individuals or groups to make complex decisions [27]. The first step in an AHP analysis is to build a hierarchy for the decision. This is also called decision modelling and it simply consists of building a hierarchy to analyse the decision (Figure 4).

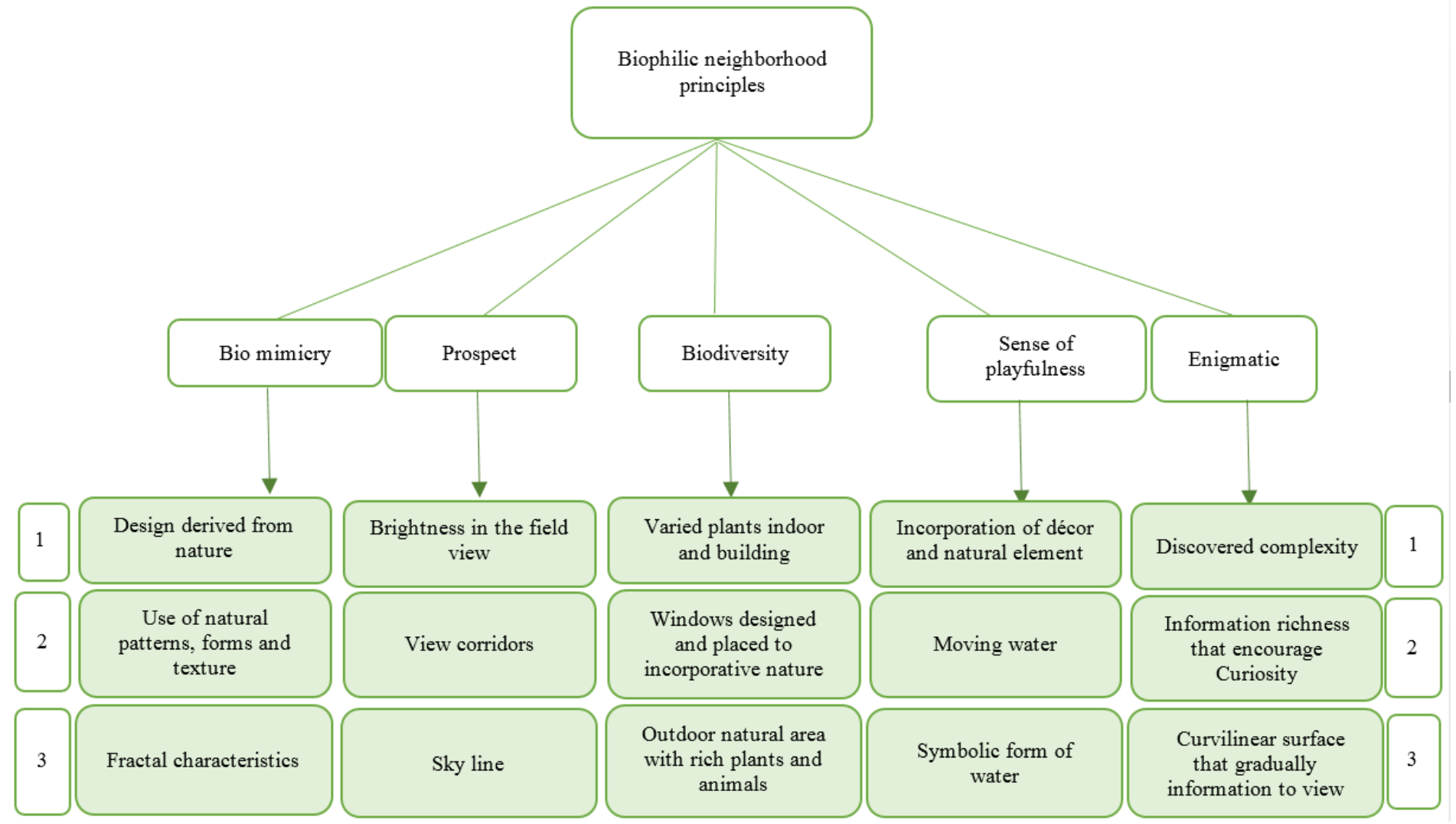

Figure 4. Hierarchy of criteria

Therefore, the second step in the AHP process is to derive the relative priorities (weights) for the criteria. It is called relative due to obtaining criteria priorities that are measured with respect to each other as we will see in the following discussion. Clearly, the importance or weight of each criterion will be different and because of this, we first are required to derive by pairwise comparisons the relative priority of each criterion with respect to each of the others using a numerical scale for comparison developed by Saaty [15] . Table 4 to 9 show comparison between (weighted) between criteria and sub criteria. Also, for comparison (weighting of patterns) between criteria has been interviewed urban planner, urban designer and architectures.

Table 4. Comparison between criteria

\begin{tabular}{cccccccc}
\hline criteria & Prospect & Bio mimicry & Biodiversity & Sense of playfulness & Enigmatic & Weight vector & Weight criteria \\
\hline Prospect & 1 & 1.5 & 1.5 & 1.3 & 3 & 0.52 \\
Bio mimicry & 5 & 1 & 1 & 1 & 3 & 9 & 0.07 \\
Biodiversity & 5 & 1 & 1.3 & 1 & 1.7 & 0.36 & 0.36 \\
Sense of playfulness & 3 & 1.3 & 1.9 & 1.9 & 0.16 & 0.22 \\
Enigmatic & 1.3 & 1.9 & & & & 0.03 \\
\hline
\end{tabular}




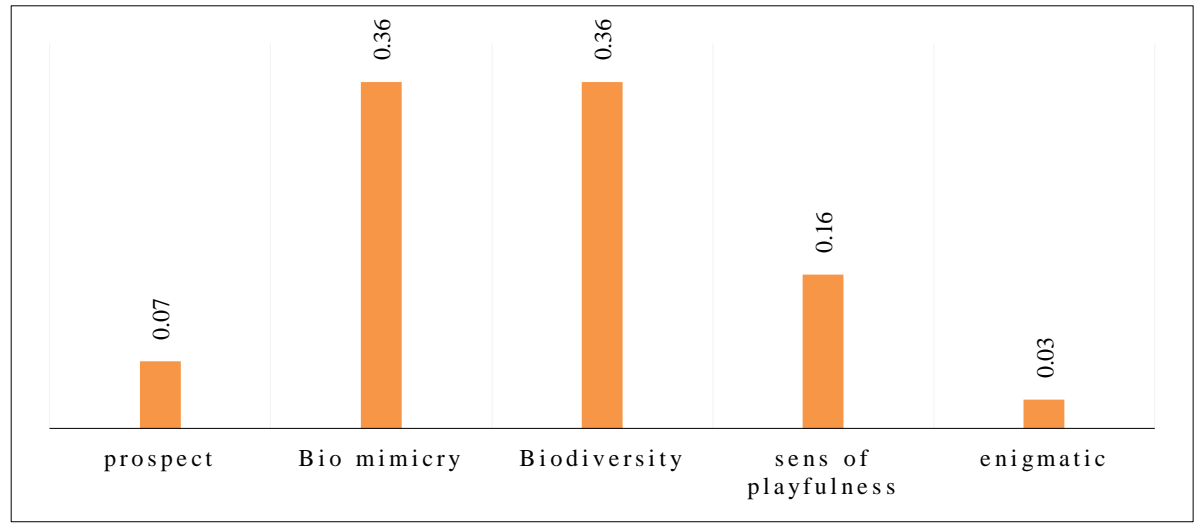

Figure 5. The weighted main criteria

At first compared between main criteria. The main criteria are prospect, bio mimicry, biodiversity, sense of playfulness and enigmatic. Based on Table 4 the maximum weight of criteria are bio mimicry and biodiversity (0.36) and the minimum weigh is 0.03 as enigmatic.

Table 5. Comparison (weighted) between bio mimicry patterns

\begin{tabular}{|c|c|c|c|c|c|}
\hline Bio mimicry & $\begin{array}{l}\text { Design derived } \\
\text { from nature }\end{array}$ & $\begin{array}{l}\text { Use of natural patterns, } \\
\text { forms and texture }\end{array}$ & $\begin{array}{c}\text { Fractal } \\
\text { characteristics }\end{array}$ & $\begin{array}{l}\text { Weight } \\
\text { vector }\end{array}$ & $\begin{array}{l}\text { Weight } \\
\text { criteria }\end{array}$ \\
\hline Design derived from nature & 1 & 1.3 & 1.5 & 0.4 & 0.10 \\
\hline Use of natural patterns, forms and texture & 3 & 1 & 1.3 & 1 & 0.25 \\
\hline Fractal characteristics & 5 & 3 & 1 & 2.46 & 0.62 \\
\hline
\end{tabular}

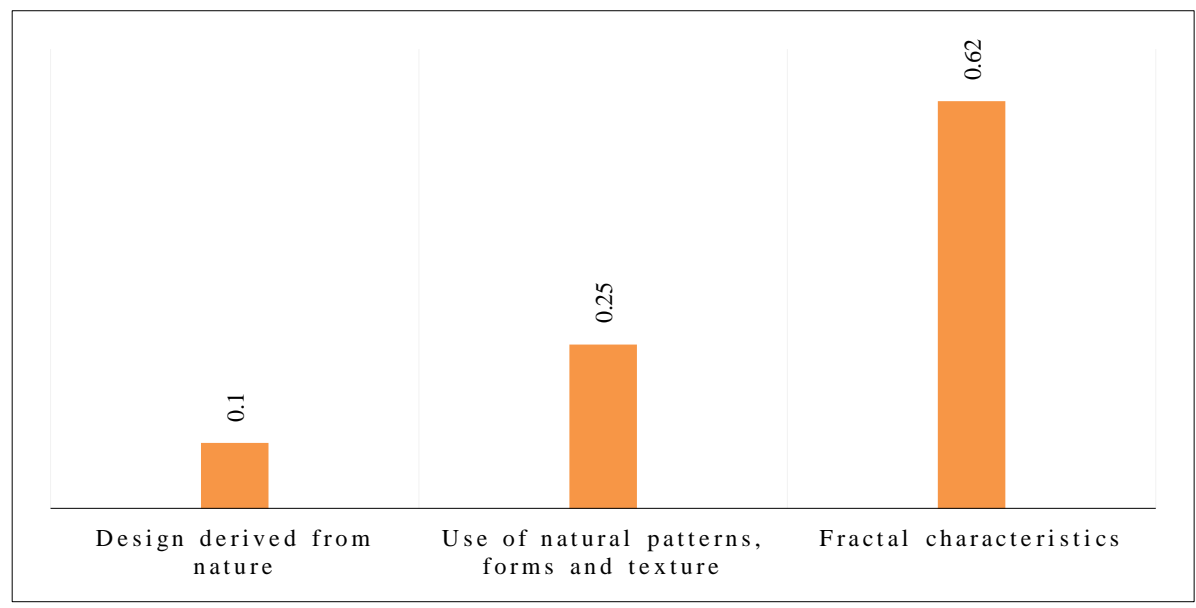

Figure 6. The weighted Bio mimicry criteria

According Table 5 the bio mimicry have three criteria. The maximum score between criteria is fractal characteristics with 0.62 score.

Table 6. Comparison (weighted) between prospect patterns

\begin{tabular}{cccccc}
\hline Prospect & $\begin{array}{c}\text { Brightness in } \\
\text { the field view }\end{array}$ & $\begin{array}{c}\text { View } \\
\text { corridors }\end{array}$ & Sky line & $\begin{array}{c}\text { Weight } \\
\text { vector }\end{array}$ & $\begin{array}{c}\text { Weight } \\
\text { criteria }\end{array}$ \\
\hline $\begin{array}{c}\text { Brightness in the field } \\
\text { view }\end{array}$ & 1 & 3 & 7 & 2.75 & 0.64 \\
View corridors & 1.3 & 1 & 5 & 1.18 & 0.27 \\
Sky line & 1.7 & 1.5 & 1 & 0.30 & 0.07 \\
\hline
\end{tabular}




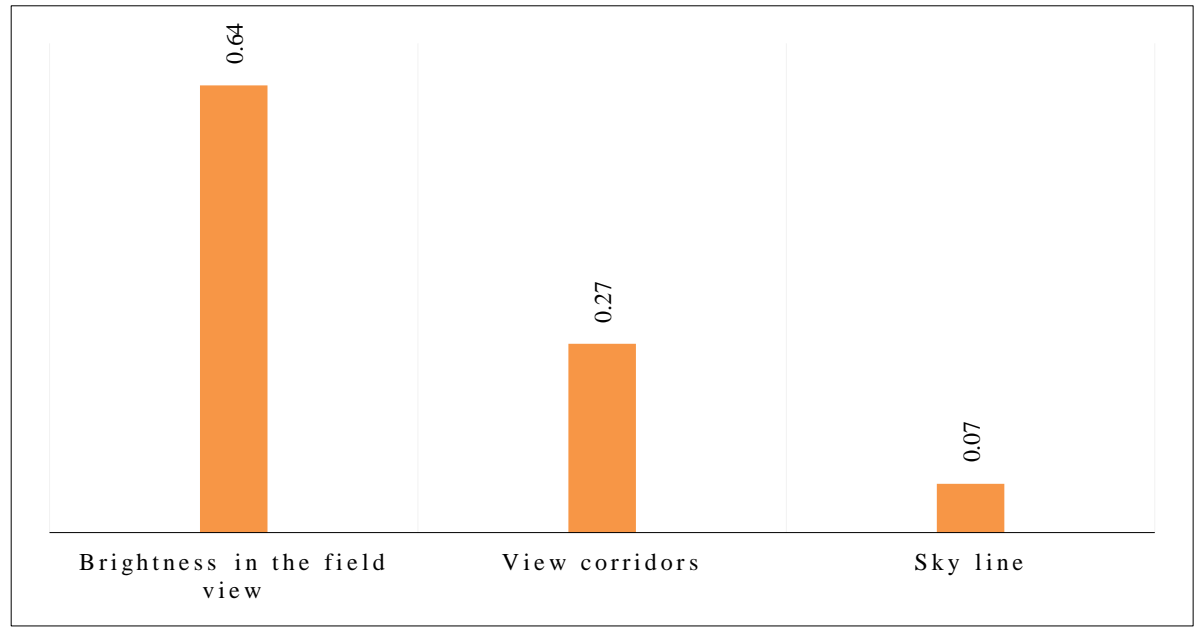

Figure 7. Comparison (weighted) between prospect patterns

Prospect criteria divided to three sub criteria. The criteria are brightness in the field view, view corridors, sky line. The best score is 0.64 as "brightness in the field view.

Table 7. Comparison (weighted) between Biodiversity patterns

\begin{tabular}{|c|c|c|c|c|c|}
\hline Biodiversity & $\begin{array}{l}\text { Varied plants } \\
\text { indoor and building }\end{array}$ & $\begin{array}{l}\text { Windows designed and placed } \\
\text { to incorporative nature views }\end{array}$ & $\begin{array}{l}\text { Outdoor natural area with } \\
\text { rich plants and animals }\end{array}$ & $\begin{array}{l}\text { Weight } \\
\text { vector }\end{array}$ & $\begin{array}{l}\text { Weight } \\
\text { criteria }\end{array}$ \\
\hline $\begin{array}{l}\text { Varied plants indoor and } \\
\text { building }\end{array}$ & 1 & 1.3 & 1.7 & 0.36 & 0.08 \\
\hline $\begin{array}{l}\text { Windows designed and placed } \\
\text { to incorporative nature views }\end{array}$ & 3 & 1 & 1.5 & 0.84 & 0.18 \\
\hline $\begin{array}{l}\text { Outdoor natural area with rich } \\
\text { plants and animals }\end{array}$ & 7 & 5 & 1 & 3.27 & 0.73 \\
\hline
\end{tabular}

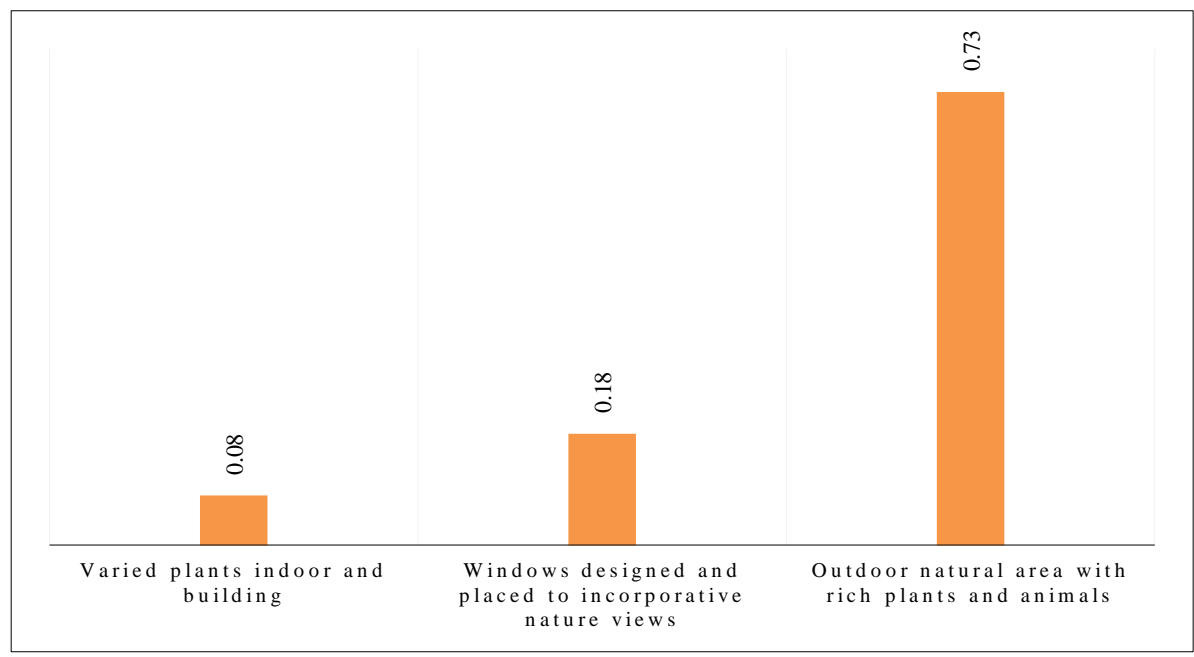

Figure 8. Comparison (weighted) between Biodiversity patterns

Table 7 shows Biodiversity criteria, there are three sub criteria. The Outdoor natural area with rich plants and animals is the most important between other criteria with 0.73 score (Table 7).

Table 8. Comparison (weighted) between Senses of playfulness patterns

\begin{tabular}{cccccc}
\hline Sense of playfulness & $\begin{array}{c}\text { Incorporation of décor } \\
\text { and natural element }\end{array}$ & $\begin{array}{c}\text { Moving } \\
\text { water }\end{array}$ & $\begin{array}{c}\text { Symbolic form of } \\
\text { water }\end{array}$ & $\begin{array}{c}\text { Weight } \\
\text { vector }\end{array}$ & $\begin{array}{c}\text { Weight } \\
\text { criteria }\end{array}$ \\
\hline $\begin{array}{c}\text { Incorporation of décor and } \\
\text { natural element }\end{array}$ & 1 & 1.5 & 1.7 & 0.30 & 0.06 \\
Moving water & 5 & 1 & 1.5 & 1 & 0.21 \\
Symbolic form of water & 7 & 5 & 1 & 3.27 & 0.71 \\
\hline
\end{tabular}




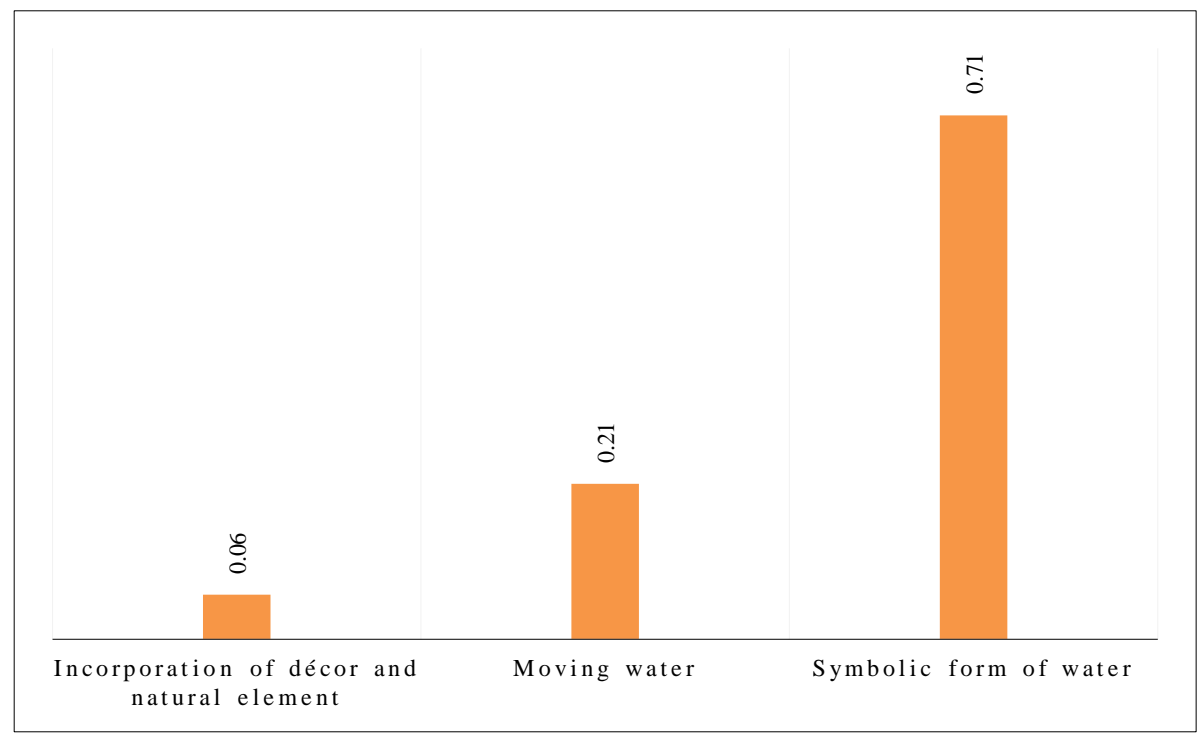

Figure 9. Comparison (weighted) between Senses of playfulness patterns

Table 8 shows Sense of playfulness criteria, there are three sub criteria. The Outdoor Symbolic form of water is the most important between other criteria with 0.71 score (Table 7).

Table 9. Comparison (weighted) between Enigmatic patterns

\begin{tabular}{|c|c|c|c|c|c|}
\hline Enigmatic & $\begin{array}{l}\text { Discovered } \\
\text { complexity }\end{array}$ & $\begin{array}{c}\text { Information richness that } \\
\text { encourage Curiosity }\end{array}$ & $\begin{array}{l}\text { Curvilinear surface that } \\
\text { gradually information to view }\end{array}$ & $\begin{array}{l}\text { Weight } \\
\text { vector }\end{array}$ & $\begin{array}{l}\text { Weight } \\
\text { criteria }\end{array}$ \\
\hline Discovered complexity & 1 & 5 & 7 & 3.27 & 0.73 \\
\hline $\begin{array}{l}\text { Information richness that } \\
\text { encourage Curiosity }\end{array}$ & 1.5 & 1 & 3 & 0.84 & 0.18 \\
\hline $\begin{array}{l}\text { Curvilinear surface that } \\
\text { gradually information to view }\end{array}$ & 1.7 & 1.3 & 1 & 0.36 & 0.08 \\
\hline
\end{tabular}

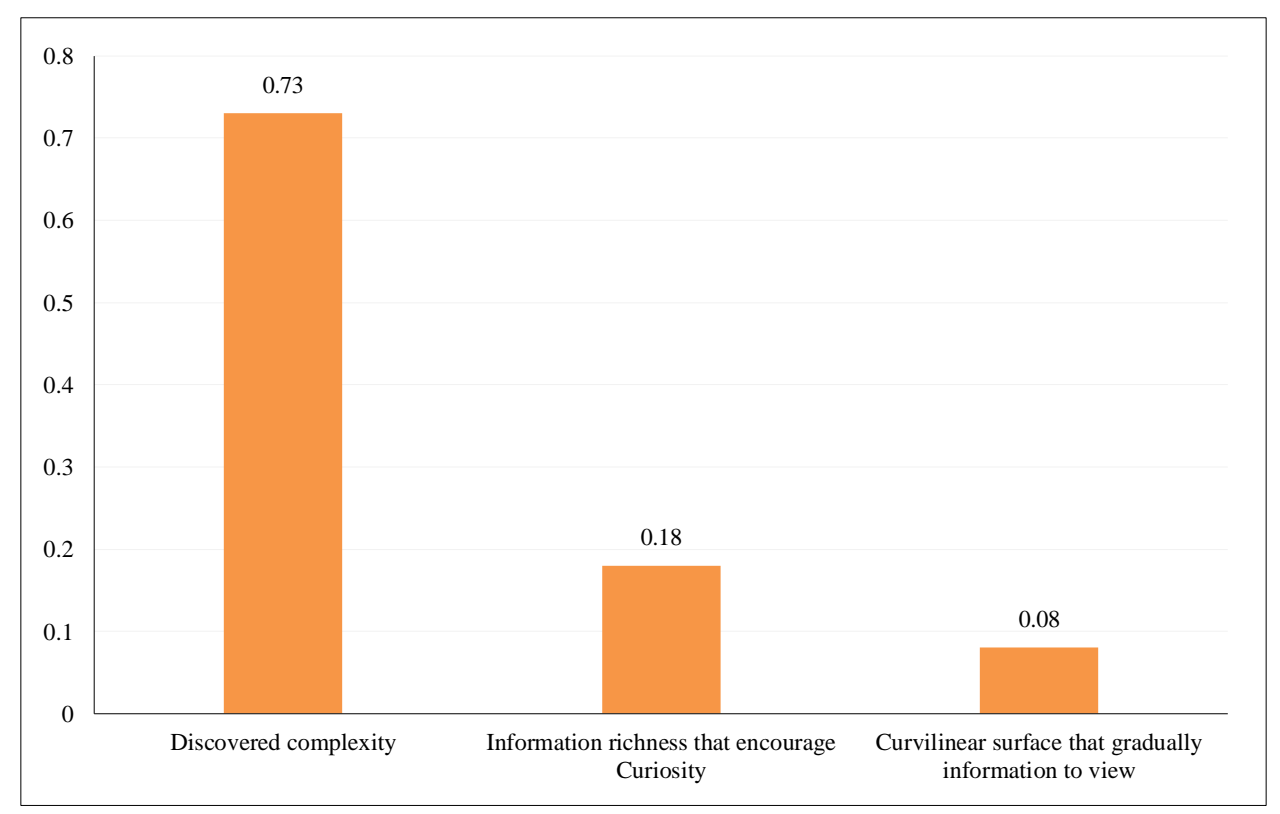

Figure 10. Comparison (weighted) between Enigmatic patterns

Table 9 shows Enigmatic criteria. There are three criteria. Based on Table 9 the Discovered complexity criteria is the most important sub criteria.

Figure 11 shows weight of criteria and patterns. In order to ranking of criteria, should be multiplied weight of criterion to other criterion weights. At finally, we reach final weight of criteria for achieving principles of Biophilic neighborhood in Iran. 


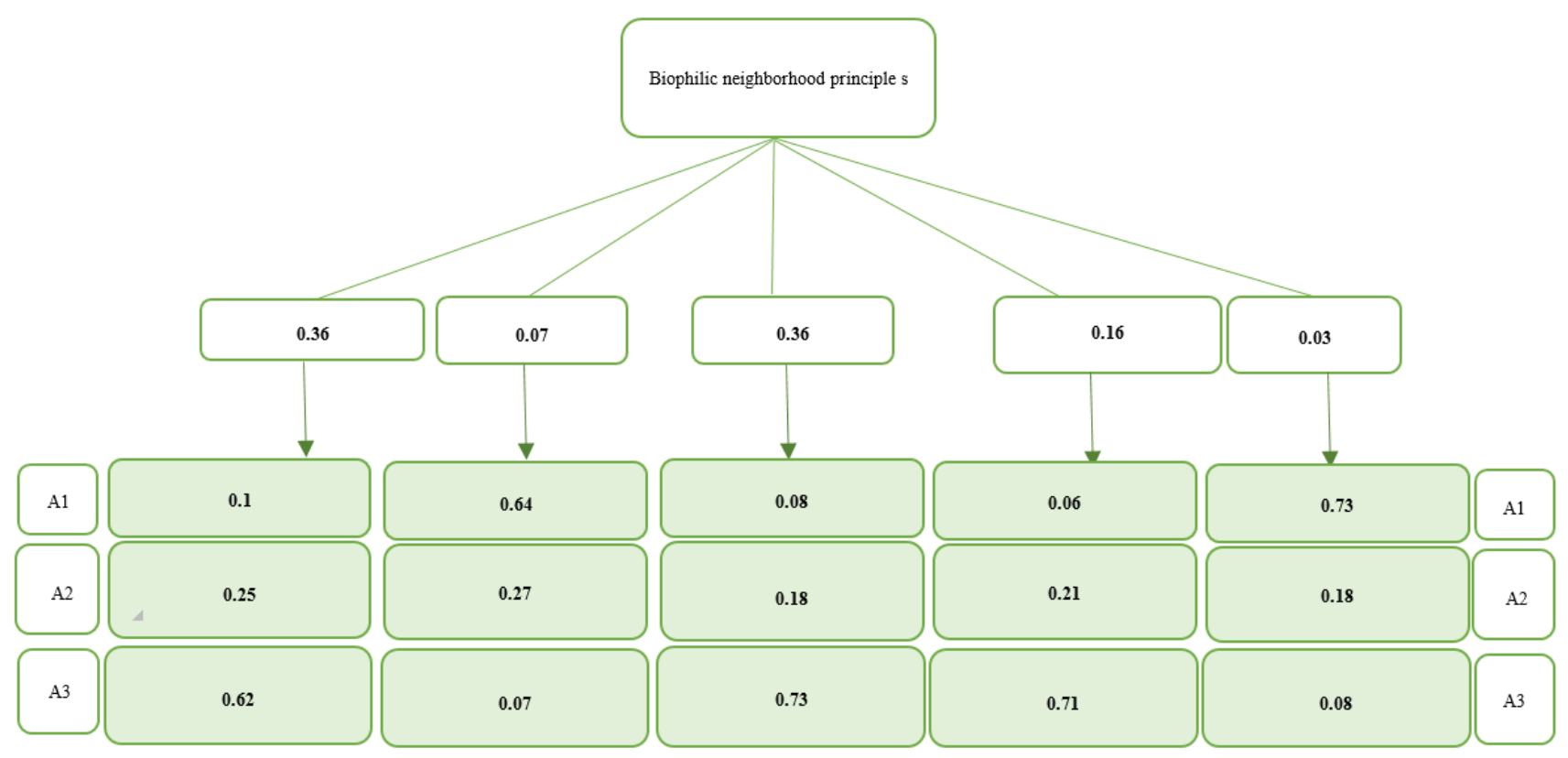

Figure 11. Weight of criteria and patterns

In addition, Table 10 shows the results of final weight for each criteria and their patterns. According to results, biodiversity criteria is the highest score between other criteria ( 0.356 score). It important principle for achieving Biophilic neighborhood in Iran. The patterns of biodiversity are varied plants indoor and building, Windows designed and placed to incorporative, Outdoor natural area with rich plants and animals. The bi mimicry criteria is second principle in order to achieving sustainable neighborhood by 0.349 score. Other criteria Such as sense of playfulness, prospect, enigmatic are important for achieving Biophilic neighborhood. Table 10, shows the Final Weight of criteria and patterns in the performance of designing based on Biophilic principles.

Table 10. Final Weight of criteria and patterns in the performance of designing based on Biophilic principles

\begin{tabular}{cccc}
\hline Criteria & Weight of criteria & Weight of pattern & Total weight \\
\hline Prospect & 0.07 & 0.64 & \\
& & 0.27 & 0.068 \\
\hline Bio mimicry & 0.36 & 0.07 & \\
& & 0.1 & 0.349 \\
\hline Biodiversity & 0.36 & 0.625 & \\
& & 0.08 & 0.356 \\
\hline $\begin{array}{c}\text { Sense of } \\
\text { playfulness }\end{array}$ & 0.16 & 0.18 & \\
& & 0.73 & 0.156 \\
\hline Enigmatic & 0.03 & 0.06 & 0.029 \\
& & 0.21 & \\
\hline
\end{tabular}




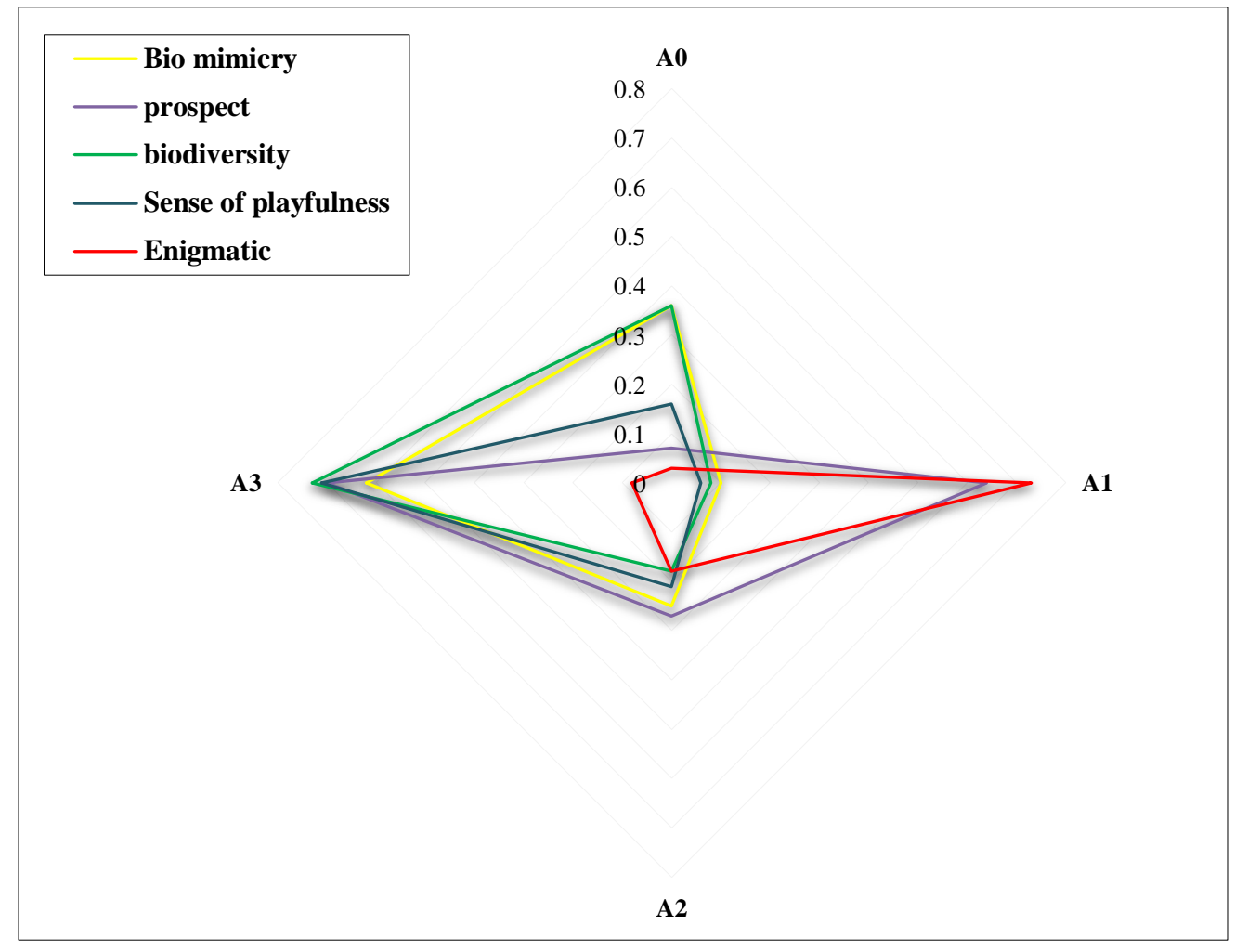

Figure 12. Final score of Biophilic criteria of Biophilic neighborhood

\section{Conclusion}

In current years, several empirical studies recording user preferences have been done to uncover the advantages of natural environments, and environments mimicking their geometrical qualities. The importance of urban green spaces and urban forests is increasing worldwide because of the expansion of urban land fuelled by urbanization. The provision of parks and green spaces in urban areas make a vital contribution to the quality of urban life. Nature is beneficial for human beings in various ways, people in cities do not get chance to have intimate contact with nature. Realizing the importance of nature in human life, theories and researches associated with Biophilia argue that we need to re-imagine cities as "Biophilic Cities" [29].

Cities around the world are growing rapidly in size and number, as they provide unprecedented economic and social opportunities. The importance of both the scale and density of cities in creating these opportunities is now well understood $[30,31]$.

The main purpose of this research is exploring principles of Biophilic elements in order to achieving sustainable neighborhood that it is adapted by Iran conditions. In this paper, five criteria was analyzed. They criteria are biodiversity, bio mimicry, prospect, sense of playfulness, enigmatic. Also was analyzed 15 patterns about this field. Findings show, the biodiversity very important in order to achieving Biophilic neighborhood. Bio mimicry is second factor in order to achieving sustainable neighborhood.

\section{References}

[1] Douglas, E., Gordon, H, Green schools as high performance learning facilities, National Institute of Building Sciences: 1090 Vermont Avenue, NW, Suite 700, Washington, DC, pp. 1-14, (2010).

[2] Hargroves, Karlson “Charlie," Cheryl Desha, and Ernst von Weisaecker. "Introducing Carbon Structural Adjustment: Energy Productivity and Decarbonization of the Global Economy." Wiley Interdisciplinary Reviews: Energy and Environment 5, no. 1 (October 27, 2015): 57-67. doi:10.1002/wene.181.

[3] Reeve, Angela Chenoweth, Cheryl Desha, Doug Hargreaves, and Karlson Hargroves. "Biophilic Urbanism: Contributions to Holistic Urban Greening for Urban Renewal." Edited by Professor Geoffrey Shen. Smart and Sustainable Built Environment 4, no. 2 (September 21, 2015): 215-233. doi:10.1108/sasbe-11-2014-0057.

[4] Sharifi, Ayyoob. "From Garden City to Eco-Urbanism: The Quest for Sustainable Neighborhood Development." Sustainable Cities and Society 20 (January 2016): 1-16. doi:10.1016/j.scs.2015.09.002.

[5] Domhardt, Konstanze Sylva. "The Garden City Idea in the CIAM Discourse on Urbanism: a Path to Comprehensive Planning." Planning Perspectives 27, no. 2 (April 2012): 173-197. doi:10.1080/02665433.2012.646768. 
[6] Brody, Jason S. "Constructing professional knowledge: The neighborhood unit concept in the community builders handbook." PhD diss., University of Illinois at Urbana-Champaign, 2010.

[7] Lloyd Lawhon, Larry. “The Neighborhood Unit: Physical Design or Physical Determinism?” Journal of Planning History 8, no. 2 (February 3, 2009): 111-132. doi:10.1177/1538513208327072.

[8] Rohe, William M. "From Local to Global: One Hundred Years of Neighborhood Planning." Journal of the American Planning Association 75, no. 2 (March 27, 2009): 209-230. doi:10.1080/01944360902751077.

[9] Beatley, Timothy. “Biophilic Cities: What Are They?” Biophilic Cities (2011): 45-81. doi:10.5822/978-1-59726-986-5_3.

[10] Beatley, Timothy. Green urbanism: Learning from European cities. Island Press, 2012.

[11] Dobbs, Richard, Sven Smit, Jaana Remes, James Manyika, Charles Roxburgh, and Alejandra Restrepo. "Urban world: Mapping the economic power of cities." McKinsey Global Institute (2011).

[12] Reeve, Angela C. "Mainstreaming biophilic urbanism in Australian cities: a response to climate change, resource shortages and population pressures." PhD diss., Queensland University of Technology, 2014.

[13] el-Baghdadi, Omniya. "Exploring the economic business case for incorporating biophilic urbanism." PhD diss., Queensland University of Technology, 2016.

[14] Mayring, Ph. "Qualitative Content Analysis [28 paragraphs]. W." In Forum Qualitative Sozialforschung/Forum: Qualitative Social Research. 2000.

[15] Saaty, T. L. Decision Making for Leaders: The Analytic Hierarchy Process for Decisions in a Complex World, Third Revised Edition. Pittsburgh: RWS Publications, 2012.

[16] Kellert, S.R.,Heerwagen,J.,\& Mador,M, Biophilic Design: The Theory, Science and Practice of Bringing Buildings to Life, John Wiley \& Sons, 2008.

[17] M. W. K. J. Y. Brengman, "The impact of in store greenery on customers," Psychol. Mark., pp. 29 (11), 807-821., 2012. Doi:10.1002/mar.20566

[18] Tifferet, Sigal, and Iris Vilnai-Yavetz. "Phytophilia and Service Atmospherics: The Effect of Indoor Plants on Consumers." Environment and Behavior 49, no. 7 (September 22, 2016): 814-844. doi:10.1177/0013916516669390.

[19] Rosenbaum, Mark S., Mauricio Losada Otalora, and Germán Contreras Ramírez. "The Restorative Potential of Shopping Malls." Journal of Retailing and Consumer Services 31 (July 2016): 157-165. doi:10.1016/j.jretconser.2016.02.011.

[20] Ebrahimpour, Maryam, Hamid Majedi, and Hossein Zabihi. “'Biophilic' Planning, a New Approach in Achieving Liveable Cities in Iranian New Towns - Hashtgerd Case Study.” Town and Regional Planning 70 (2017). doi:10.18820/2415-0495/trp70i1.1.

[21] Nielsen, "2014 State of the Shopping Center," Accessed 17 May 2014. [Online].

[22] Reynolds, Kristy E., Michael A. Jones, Carolyn Findley Musgrove, and Stephanie T. Gillison. “An Investigation of Retail Outcomes Comparing Two Types of Browsers." Journal of Business Research 65, no. 8 (August 2012): 1090-1095. doi:10.1016/j.jbusres.2011.09.001.

[23] Kellert, Stephen. "Biophilic Urbanism: The Potential to Transform." Edited by Cheryl Desha, Angela Chenoweth Reeve, Pete. Smart and Sustainable Built Environment 5, no. 1 (April 4, 2016): 4-8. doi:10.1108/sasbe-10-2015-0035.

[24] Reeve, A., Desha, C., Hargroves, K., and Newman, P, " Informing healthy building design with biophilic urbanism design principles: a review and synthesis of current knowledge and research," in Healthy Buildings Conference 2012, Brisbane, 8-12 July, 2012.

[25] Littke, Hélène. "Becoming Biophilic." Edited by Cheryl Desha, Angela Chenoweth Reeve, Pete. Smart and Sustainable Built Environment 5, no. 1 (April 4, 2016): 15-24. doi:10.1108/sasbe-10-2015-0036.

[26] Birkeland, Janis Lynn. "Net Positive Biophilic Urbanism." Edited by Cheryl Desha, Angela Chenoweth Reeve, Pete. Smart and Sustainable Built Environment 5, no. 1 (April 4, 2016): 9-14. doi:10.1108/sasbe-10-2015-0034.

[27] Brunnelli, M. Introduction to the Analytic Hierarchy Process, Springer, 2015.

[28] Salingaros, N., and K. Masden. "Neuroscience, the natural environment, and building design." Biophilic Design: The Theory, Science and Practice of Bringing Buildings to Life. New York: John Wiley (2008): 59-83.

[29] Beatley, Timothy. "Biophilic Cities: Integrating Nature into Urban Planning and Design." Washington, DC (2010).

[30] Glaeser, E. "The Triumph of the City. London." Pan Macmillan (2011).

[31] Newman, Peter, and Jeffrey Kenworthy. Sustainability and cities: overcoming automobile dependence. Island press, 1999. 